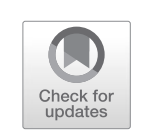

9

\title{
The Anatomy of the Social Question and the Evolution of the Brazilian Social Security System, 1919-2020
}

\author{
Lena Lavinas
}

\section{Brazil: A Crude Path to Modernity}

Brazil's slide into modernity has been marked by the brand of exclusion. Ours was a crude modernity, built on negation and the stifling of citizenship, whether in terms of civil, political, or social rights.

At each level of development, at each new cycle of economic growth, under authoritarian regimes or living in democracy, in crises or during periods of reconstruction, the anatomy of Brazil's social question reflects tensions over the fight for inclusion and the struggle to carve out a social existence, and the forces resisting that change. The shape of social policies

\footnotetext{
My thanks to Angela de Castro Gomes, Ana Carolina Cordilha, Andrej Slivnik, and José Maurício Domingues for their valuable contributions to this chapter. I also benefitted from the stimulating reflections of Lutz Leisering and a group of intellectually engaged scholars who contributed with their critiques to a previous draft (see the much more detailed working paper Lavinas 2020). Finally, I would like to thank Flora Thompson-DeVeaux for her talent in translating the original manuscript from the Portuguese.
}

L. Lavinas $(\bowtie)$

Institute of Economics, Federal University of Rio de Janeiro, Rio de Janeiro, Brazil

(C) The Author(s) 2021

L. Leisering (ed.), One Hundred Years of Social Protection, Global Dynamics of Social

Policy, https://doi.org/10.1007/978-3-030-54959-6_9 
and their progress through time mirror that clash, or the silencing thereof. They are thus the final expression of the struggle for public recognition of the people's demands.

As we argue, in Brazil, the essence of the social question, or the process of the construction of citizenship, developed fairly independently from the construction of the social protection system, although Social Security, instituted by the 1988 Citizen Constitution, is one of the most remarkable conquests on that score.

The aim of this chapter is twofold. First, it develops a periodization and typology of the multiple historical configurations of the social question in Brazil over the past 100 years in order to observe its relationship with the construction of the social protection system, Social Security, in particular. As guaranteed in the 1988 Constitution, that system includes social insurance, social assistance, and public healthcare. Second, the chapter systematizes how social movements, conflict-led dynamics, labour, and different regimes of accumulation shaped social policies and citizenship, contributing to define patterns of inclusion-which varied over time, lending new form to the social question, the many facets of which seem to form a kaleidoscope of "social questions".

Over the course of this chapter, we seek to demonstrate that, in the span of just over a century, the social question took on a variety of forms, but was repeatedly marked by the struggle for recognition and the fight for inclusion-a strong indication that the process of constructing citizenship has been something of a permanent effort to break down boundaries.

In addition to the introduction and conclusion, the present chapter is divided into four sections. This structure reflects the periodization adopted in attempts to characterize the essence of the social question, which expresses itself in terms of clashes between society and the State. These phases are associated with changes at the level of the political regime, patterns of development, the shape and function of institutions, and the agendas driven by the social conflicts that they spring from. They include struggles for labour rights, access to land, democracy, better living conditions, equality, inclusion, mobilization against racism and sexism, and the fight to preserve rights that, once attained, are immediately threatened and contested. 
Following this introduction, the second section covers 1899-1929 and is divided into two subsections. In this phase, the social question is, above all, "the question of the needs of the people" (Castro Gomes 2005: 49).

The third section focuses on the period that saw the construction of regulated citizenship (Dos Santos 1979): 1930-1963, a span that includes a prolonged authoritarian period (1930-1945) but also a democratic respite (1946-1963). The State led the charge on this front. With the consolidation of social insurance for a small portion of the working class, the social question was transformed into a regional question, framed by the struggle for increased access to land.

In the fourth section, the chapter situates the social question within the struggle for democracy and against inequality, mobilizations that would swell and multiply throughout both the "economic miracle" and the severe recession that followed.

The fifth section goes from the civil-military coup of 1964, which entailed a loss of political rights, to the mid-1980s, when the severity of the economic crisis broke the prevailing political pact and led the military to support a "slow, gradual, and secure opening". During this phase, the social question may be defined as the democratic question, coupled with the fight against inequalities.

The final section analyses the period after re-democratization (post-1988), which brought a transition to a civil government and the reinstatement of open elections for the presidency. Here, the social question would become the question of full, unrestricted citizenship in the attempt to build a new Brazil (Paoli 1989). Social Security was implemented, broadening the scope and scale of social protection and introducing universal rights for the first time in Brazil's history.

\section{9-1929: The Social Question as the Needs of the People-Under the First Republic- Repression, Concealment, and Reshaping}

Two phases precede the classical model of associating the social question to labour and the emergence of the social protection system. 
In the first phase, which we place between the proclamation of the Republic in 1889 and the end of the 1910s, the social question was framed by grassroots movements around the cost of living, the right to housing, and unionization. This time frame is also justified by the fact that in 1919, Brazil — as a signatory of the Peace Conference and Treaty of Versailles, which led to the creation of the International Labour Organization (ILO) — formally recognized the power of the international workers' movement, with important consequences for domestic policy. As a founding member of the ILO, Brazil took part in the first International Labour Conference that year and adhered to the tripartite system of representation determined there, bringing together governments, employers, and employees.

Brazil's adhesion to institutions such as these, which would begin to mould relations within this new community of nations and implement a new international order, would have an important effect on the framing of its first labour laws.

The second phase, between 1919 and 1929, saw the discussion and passage of the country's first social laws to regulate wage labour, and the first initiatives designed to ensure the right to retirement benefits and pensions.

To the eyes of many authors (Castro Gomes 1979, 2005; Cardoso 2010), the 1920s were the years in which the social question shifted from the struggle over the cost of living and a lack of affordable housing - a broad-ranging movement that had become increasingly radical over the years - to the field of labour rights in a strict sense. At stake were the number of work-hours per week, women and minors at work, vacation time, and the lingering, urgent matter of occupational accidents-compensation for which, when it did come, depended on the goodwill of one's employer.

The introduction of the Commission on Social Legislation in the Chamber of Deputies in late 1918, as well as the first vote on the Occupational Accidents Law in 1919, would contribute to redefine the social question and lend it new centrality. Both measures reflected the strengthening of the workers' movement on an international level and provoked a backlash from national elites. 
Employers worked to restrict the measures as best they could, looking to avoid excesses that might undermine their process of accumulation. In the words of Castro Gomes (1979), employers put on a united front that was complex and contradictory: on the one hand, their stance preserved "the classical principles of liberalism, defending the 'freedom to work,' but gradually grafted onto it an acceptance of state intervention, an acceptance that was forced upon them and limited to specific issues" (163).

In 1915, the federal government had put forth a bill proposing mandatory compensation for occupational accidents. While the proposal remained tabled for a number of years, it would be joined by other issues, such as the establishment of a minimum wage for industrial workers. These scattered demands were the reflection of budding pressure, born of the advance of industrialization and urbanization.

The period was thus shaped by the emergence of a regulatory framework focused on wage labour, meeting the needs of a very small subsection of the working population.

The business community lobbied for women to be able to work the same hours as men, instead of daily shifts of up to six hours. ${ }^{1}$ They supported a ban on work for minors under 10 (not 12), spoke in favour of a minimum age of 15 (not 16) for a young person to be considered an adult on the labour market; pressed for a 56-hour work week; and opposed the establishment of schools and childcare facilities within factories, a long-time demand of social movements. In other words, they contested the workers' demands, point by point.

They did, however, accept the establishment of private workers' compensation policies (for minor accidents, death, or disability), taken out with insurance companies. These policies only covered the worker in question, with no provision for dependents, and would not trigger payment of retirement benefits or pensions for those who ceased to work. In other words, they vehemently denied the creation of Social Security. And it would be on these terms that the occupational accidents bill would

\footnotetext{
${ }^{1}$ They successfully contested the idea of banning women from working night shifts, as well as eliminating a proposal that would have ensured a period of rest (with two-thirds of pay) before and after childbirth (Castro Gomes 1979: 177).
} 
finally pass in 1919, the regulatory cornerstone of the nation's social protection system.

The capital-labour conflict was transformed into an individual, external issue, regulated by a contract and designed to be dealt with between the worker and the insurer. In the words of Dos Santos (1979), "until 1924, suits over occupational accidents would remain in the realm of private conflicts. Strictly speaking, they were matters for the police, and victims had to request an investigation" in order to determine whether or not compensation was in order.

Thus, the event commonly celebrated as the first conquest of the incipient working class-protection against accidents in the workplace-fell outside the scope of public social insurance. The Eloy Chaves Act, passed in 1923 (see later), likewise failed to include worker's compensation as a part of the incipient social protection system. It would remain subject to private contracts, outside the realm of social rights. For the next 40 years, employers' associations staunchly opposed the adoption of collective, contributory, public insurance systems.

In 1921, the social question remained present, and it would make its presence felt in the heated electoral debate. But not even that could guarantee the effective functioning of the National Department of Labour, which had been created in 1917 in response to a wave of strikes. The aim was to monitor compliance with the laws that were beginning to establish a new system of protection for labourers. Due to pressure from business interests invested in delaying and hindering the effective application of these new laws, the department would remain functionally inoperative. In its stead came the National Labour Council (Conselho Nacional do Trabalho, or CNT), instituted in 1923, even as the government aggressively repressed mobilizations by the emergent working class. Workers on the federal and state railways had been on the point of outright rebellion, and their walkouts during the general strikes had seriously affected other productive sectors. They were the most organized and mobilized group calling for workers' rights.

These obstacles, however, failed to foil some of the most important institutional innovations of the so-called First Republic (1889-1930). One was the Eloy Chaves Act of 1923, which created the nation's first fully funded pension scheme by instituting the Pension and Retirement 
Fund for the workers on the São Paulo Railway. The Fund would also provide other labour-related benefits. In addition, there were the Lei de Férias (which regulated vacation time) and the Código de Menores (which stipulated working conditions for minors). The Pension and Retirement Funds (CAPs) were created in Brazil at the initiative of a group of lawyers, businessmen, and public figures (Malloy 1986), strongly influenced by Argentina, where similar funds had been in place since 1904.

Not even this would blunt the impact of the Funds on the ascendant Brazilian business class, which believed that it would be essential for the State to act, not as a gendarme, but now as a "machine for progress" (Pio Vieira 1978: 119). This was the tone taken by the leader of the movement in Brazil, federal deputy Eloy Chaves, a scion of the colonial oligarchical elite and the Paulista aristocracy.

Eloy Chaves' proposal revealed a Bismarckian inspiration, relying on mandatory contributions from both employees and employers to a selfadministered, non-state pension fund. The project called for a broad range of other provisions: medical care and medication for the policyholder and his family; regular retirement benefits; pensions for employees' heirs; immediate coverage of funeral expenses; and disability retirement. The fund was to be administered by the beneficiaries themselves (Pio Vieira 1978: 236), with the participation of the employer.

Chaves proposed a constellation of decentralized funds outside the umbrella of the State and administered by the private sector. He opposed a general rule for pensions and the creation of a public fund. True to his liberal values, he put his foot down at State intervention into the provision of retirement benefits and pensions.

The act was finally passed in January of 1923. Each railway company would have to create a retirement and pension fund for its employees (whether permanent or temporary). The funds would be fed by monthly contributions from employees (3\% of their salary) and an annual contribution from the railway companies ( $1 \%$ of gross income $\left.{ }^{2}\right)$; and the State would not contribute funds of its own, but would allocate revenue from

\footnotetext{
${ }^{2}$ Dos Santos (1979) clarifies that, in the absence of oversight, the $1 \%$ contribution was effectively made, not based on gross revenue but rather the wage bill. This situation persisted through the 1960 s, substantially reducing the employer's contribution.
} 
an extra tax of $1.5 \%$ on railway fares. These resources would be deposited in a special account in a bank chosen by the administrators of the Fund, with no government participation, and would be put towards purchasing national or state bonds. ${ }^{3}$

Old-age pensions were calculated based on the worker's average salary over their last five years of service, granted after 30 years of service and 50 years of age, ${ }^{4}$ and were lifelong. Moreover, a worker who suffered "total and permanent disability [would] have the right to retirement, no matter the length of his service" (Pio Vieira 1978: 267). Retirement benefits for the disabled would be equivalent to $50 \%$ of the retirement benefit received by workers with over 30 years of service and $25 \%$ for workers who had between 10 and 30 years of service. It would not be possible to receive multiple regular old-age pensions or retirement benefits concurrently.

The most important part, which had to do with the model of capitalization, is laid out specifically in Article 39: "Retirement benefits and pensions may be lesser than stipulated in this law if resources in the Fund cannot sustain the respective charges, and this may be the case while resources remain insufficient" (Pio Vieira 1978: 271). In other words, the rule established a defined contribution and an undefined benefit, exempting the employer from guaranteeing a true substitute income in the period after one's working life.

Attempts to extend the Eloy Chaves Act to major companies in all sectors soon followed, while resistance to the law spread within the railway sector. Chaves himself came out against proposals that sought to expand the model to other sectors and attempts to involve the State in financing pensions. In his vision, the new Funds ought to live off of their own resources and go without public financing, unlike the classical Bismarckian model, which included state subsidies. More generally, "State contribution had to be avoided at all costs in the structuring of any other Funds for any other categories of workers" (Pio Vieira 1978: 300).

\footnotetext{
${ }^{3}$ Law 4.682 of January 24, 1923. Pio Vieira (1978: 266).

${ }^{4}$ The initial recommendation was a minimum age of 55 , but, under pressure from the railway workers, Eloy Chaves reduced it to 50 .
} 
Thus, we need to qualify the classical reading that the corporative, paternalistic structure of the government under the First Republic was responsible for developing Brazil's first mechanisms of social protection (Slivnik 2018).

The CAPs would stand as the country's main social insurance model through 1931, when the system underwent its first reform. By then, some 98 company-specific Caixas had been created, covering close to 147,000 members (Slivnik 2018).

According to Slivnik (2018), the CAPs persisted throughout the 1920s as "civil societies run by Advisory Boards, composed of representatives for employers and employees, which were to determine [the Fund's] investment policy and deliberate over the concession of retirement benefits and pensions" (45). The Chaves Act rejected the mutualist tradition developed within the workers' movement, which had been able to offer lowcost medical services and medicine.

On another legislative front, the country saw increased regulation of wage labour. Employer associations' attempts to quash the approval of vacation rights came to naught. A law guaranteeing 15 days of vacation for employees, labourers, and workers at banks and other institutions was passed in 1925 (Castro Gomes 1979). The legislation would not go into effect for factory workers until 1930, however, thanks to violent resistance on the part of the industrial bourgeoisie and the indifference of the governing authorities.

Child labour would be regulated in 1927; underage workers were a considerable contingent of the agricultural workforce, but also in rapidly expanding urban sectors, especially industrial production. Employers successfully proposed that youth aged $14-18$ be treated as adults, while children of ages 10-14 would be able to work up to six hours per day.

The balance of these first few decades of republican rule is fairly slim. Despite minor advances in terms of labour regulations, the absence of compliance oversight and repeated stonewalling on the part of employers in commerce and industry hamstrung hopes of more far-reaching gains for urban workers. In the 1930 s, only $3 \%$ of the working population were covered by these new labour regulations (D’Araújo 2019).

We may, however, safely dismiss the idea that before the Vargas era, the social question was treated as "a matter for the police" (D’Araújo 2019; 
Castro Gomes 1979). At this point in time, it combined both dimensions. "Social legislation far beyond the political aim of ensuring social peace and spill over into the economic realm, as coercion made it possible to secure greater productivity from the workforce" (Castro Gomes 1979: 215).

In addition of being incipient, the foundations of the Brazilian labour and social insurance legislation left out the majority of those working on the streets or at odd jobs.

\section{0-1945: The Social Question as a Workers' Question}

The Revolution of 1930, that put an end to the First Republic, was a military coup d'état led by Getúlio Vargas, who had run for president in 1930 as the candidate of the Aliança Liberal (Liberal Alliance). The Alliance's motto was "Let us carry out the revolution serenely, before the people do it violently". This newly formed coalition cast itself as an alternative to the political establishment represented by major coffee producers and exporters, who had dominated the system during the First Republic. Getúlio was defeated; the administration's candidate, a representative of the São Paulo oligarchs, won but was kept from taking office by the coup. Getúlio Vargas became the head of the Provisional Government, awarding himself broad powers. The 1891 Constitution was revoked, and Vargas began governing by decree. A new constitution would only be put in place in 1934 .

Before leading the military coup, Getúlio Vargas - who was to govern Brazil through an authoritarian regime from 1930 to 1945-once declared on the campaign trail: "We cannot deny the existence of the Social Question (questão social) in Brazil as one of the problems that must be addressed seriously by the authorities. What little we have in terms of social legislation is not applied, or only the smallest part of it is, sporadically, despite our commitments in that regard as signatories of the Treaty of Versailles." 5

\footnotetext{
${ }^{5}$ Speech made on January 2, 1930, in Rio de Janeiro. Documents from Biblioteca Nacional, 1963.
} 
Brazilian social legislation was moved forward by an unprecedented international scenario in which multilateral accords took on the strength of legislation. But in the real world, that very legislation was powerless. Still, Vargas pointed out a social question, and it would fall to the State to address it. This would be one of the great legacies of the Vargas Era: the construction of an institutional framework designed to protect labour and workers, albeit during a period of authoritarianism and the repression of unions and grassroots movements, leaving out the majority of non-regular workers.

Social policy post-1930 focused on the matter of labour, a central pillar of the new regime of accumulation. This new social engineering was, in Vargas' words, ${ }^{6}$ designed to overcome "pauperism and all the ills that stem from an excess of activity without fixed occupation". It began with the creation, following the Revolution of 1930, of the Ministry of Labour, Industry, and Commerce, and the foundation of the National Department of Labour in $1931 .^{7}$ Finally armed with an institutional structure designed to analyse, formulate, and execute social and labour laws, the State would take vigorous, direct action towards regulating capital-labour relations, supported by a new union law approved the same year, which would repress, delegitimate, and demobilize free unionization (which had been legal since 1907). To this end, one of the new government's first measures was a 1931 law governing unions.

In order to exist, any union organization would have to be formally recognized by the Ministry of Labour. Employee and employer unions were instituted, organized by branches and professions. The new union law also stipulated that, from 1943 onward, it would become compulsory for every worker in a given category to pay a union tax. These new unions were denied the right to political or ideological manifestations and ultimately served to stand beside the government in defending the economic, social, and legal interests of their professional categories; drawing up contracts; maintaining cooperatives; and providing social services (D’Araújo 2019). In practice, over the 1930s, Vargas' social legislation led to the

\footnotetext{
${ }^{6}$ Vargas in 1938, quoted by Cardoso (2010: 786).

${ }^{7}$ The measure had first been proposed in 1917 , but it was blocked by uncompromising resistance on the part of employers.
} 
destruction of autonomous unions and the independent organization of the working classes.

Only unionized workers would enjoy the benefits of labour legislation and its associated rights (including vacation), and only they could participate in collective bargaining. Non-union members were also unable to file official complaints (Dos Santos 1979). At its root, then, the legal and institutional framework taking shape thus worked to set peers apart.

Before 1930, the Brazilian government had taken a liberal approach to the unions, repressing their mobilizations while refraining from regulating them. The period that followed saw the making of state-led, corporate unionism, guided by the principle of the "collaboration between classes". ${ }^{8}$ Independent unions were subject to interventions and police invasions, and their members might be jailed (Castro Gomes 2005).

Starting in the early 1930s, despite the grave economic crisis that had overtaken the country in the wake of the 1929 crash, an important set of measures would broaden the scope of the regulation of the labour market in a move to encourage the ongoing accumulation process. They included the official recognition of certain professions; the first rules governing the adoption of collective agreements; wage equality; workday laws in industry and commerce; new rules about the employment of women and minors; and a law that "nationalized" the workforce (requiring that twothirds of employees be Brazilian citizens).

The employment record book of 1932 became a watershed, separating out urban workers who were gainfully employed, belonged to recognized, State-regulated professions, and bore the official stamp of the union. This configuration thus established a durable, stubborn link between one's employment record book, one's status as a unionized worker, and access to social benefits.

In 1934, a new Constitution would introduce the labour court system. At that point, it was overseen by juizes classistas, union representatives who stood in as labour judges. This indirectly expanded executive action into the realm of the judiciary, concentrating more power in state hands when it came to adjudicating labour conflicts.

\footnotetext{
${ }^{8}$ A turn of phrase coined in 1931 by Senator Lindofo Collor, then Minister of Labour.
} 
Dos Santos (1979) refers to this complex process of constructing new institutions as regulated citizenship:

All members of the community who find themselves in any occupation recognized and defined by law are considered citizens. Citizenship is thus expanded through the regulation of new professions and/or occupations, first of all, and through the broadening of the scope of the rights associated to said professions, rather than the expansion of the values inherent to the concept of belonging to the community. Citizenship is embedded within one's profession, and the rights of the citizen are limited to the rights relevant to his place in the productive process, as enshrined in law (75-76).

Of course, this regulated citizenship was aimed at industrial workers, who were relatively few in number, and failed to take in the rural population: in $1940,70 \%$ of the population lived in rural areas, and only $3 \%$ of that group owned land (Cardoso 2010). Rural poverty would be addressed not through agrarian reform-eternally postponed and sidestepped (see Chap. 10, in this book) — but by expanding the nation's agricultural frontier and occupying Amazonia and the Centre-West, seen as demographic voids. This made it possible to boost the meagre productivity of smallscale rural production without touching highly concentrated landholdings — and hence without challenging the bases of reproduction for many of the country's elites.

When it came to rights and benefits, social policy came to reproduce the same stratification instituted in the job market, setting apart those recognized as workers from the masses without citizenship. In the process, antagonisms and divisions were fostered amongst working people who were afforded different statuses.

One of the first measures in the realm of social protection would be the reform of the Old-Age Pension and Retirement Funds (CAPs), in 1931. The Eloy Chaves Act was modified: the benefits afforded to railway workers were now extended to the employees of other companies that provided public utility services (transportation, electricity, telegraph and telephone service, water and sewage). This expansion did not challenge the company-specific model, nor did it alter the financing rules 
stipulating that State representatives could not participate in the Advisory Boards.

While the number of CAPs would continue to rise (by 1936, there were 189, as opposed to 98 in 1931) (Slivnik 2018), their institutional status was shaken by the restructuring of the social insurance system, which came under State control, with the creation of the Institutes of Retirement and Old-age Pensions (Institutos de Aposentadoria e Pensóes, or IAPs) in 1933.

The first IAP was created for maritime workers and would set the mould for the rest. From 1934 onward, other professions would create their own Institutes, among them commercial employees (IAPC), bank employees (IAPB), industrial employees (IAPI), and transportation and cargo workers (IAPTEC). This movement would gradually lead to the reorganization of the CAPs (one was created for civil servants in 1939).

Both models_CAPs and IAPs — would persist through the 1960s, functioning in different ways. Not only did they move away from the company-specific framework and bring together all the workers in a given sector across the nation, but the IAPs also included federal representatives on their Advisory Boards who were tasked with appointing the chair. Slivnik points out another relevant difference: "the funds corresponding to the State's quota, for IAP contributions, which were obtained through newly created fees and taxes, now went through the National Treasury, unlike the Eloy Chaves Act, wherein the funds were collected by the companies themselves and deposited directly into the Funds" (Slivnik 2018: 54-55). This would seem to be the expression of an actuarial concern on the part of the State, which now also began to use the resources saved up in the IAPs.

By separating out the workers recognized as such into sectors controlled by State-authorized unions, the emergent social insurance model maintained the splintering of horizontal solidarity and heightened the struggle for benefits specific to each category.

The problems caused by this fragmented model are well known. They would be listed in an ILO report published in 1935 by the Ministry of Labour, Industry, and Commerce. ${ }^{9}$ Among other measures, the report

\footnotetext{
${ }^{9}$ In 1934, Adrien Tixier, an ILO employee and specialist in Social Security, came to Brazil on an independent mission to evaluate the incipient social insurance system (see Slivnik 2018: Chap. 2).
} 
suggested the creation of the National Institute of Social Insurance (INSS) to unify the social insurance system and provide uniform rights and benefits; to set up regional funds with a minimum of 50,000 associates per organization (to ensure financial solvency and resilience) ${ }^{10}$ and that Brazil's social insurance legislation be brought into greater compliance with the international conventions led by the ILO. ${ }^{11}$

The recommendations fell on deaf ears, and the IAP model was enshrined in 1937, the year in which Vargas proclaimed the Estado Novo (the new state), quashing individual and political freedoms and tightening control over unions.

As Vargas put it in 1938, responding to complaints of his curtailing of individual freedoms: "The Estado Novo does not recognize the rights of individuals over the collective. Individuals do not have rights, they have responsibilities!” The National Security Law of 1935 had already hammered a nail into the coffin of social movements, turning the social question into a matter of national security (177), in light of the Communist threat (Castro Gomes 2005).

Despite the advance of the social insurance system, the severe deficits in the country's social protection network were countless and unquestionable, as conservative ideologues and jurists ${ }^{12}$ associated with the Varguista push did not deny. In the early 1940s, disability benefits were far below subsistence level; those in search of outpatient services or hospitalization would find few options; and there was no credit available for low-income housing, one of the great demands at the time.

Moreover, very few enjoyed that insufficient protection to begin with. According to the 1940 Census, out of " 26.8 million workers, only $16.6 \%$ could be considered potential beneficiaries of social insurance under the legislation governing CAPs and IAPs. Among those 'left out' (those whose professional activities went unrecognized by law), 9.4 million were rural workers, 2.9 million worked in undefined or undeclared professions, and

\footnotetext{
${ }^{10}$ At that point, $80 \%$ of CAPs had fewer than 1000 covered members.

${ }^{11}$ Compensation for work accidents (1925); work-related illnesses (1925); equal treatment for foreign and domestic workers (1925); compulsory health insurance (1927); and compulsory disability, old age, and death insurance (1933).

${ }^{12}$ On this, see Cardoso (2010) for a deep analysis of the works of Oliveira Viana as a consultant for the Ministry of Labour under Vargas.
} 
9.9 million were domestic workers"13 (Slivnik 2018: 98, 200), generally unremunerated. Even in the trades covered by legislation, coverage ranged between one-fourth and three-fourth of workers; by 1940, coverage was far from complete (Slivnik 2018).

Finally, these various institutes and funds did not provide unemployment insurance or any sort of aid for workers who left the job involuntarily. Nor were the benefits provided uniformly, except in the case of retirement benefits and pensions, which were the cornerstone of the system. Different sums and rules applied across each sector. ${ }^{14}$ As Werneck Vianna (1998) explains, medical assistance was only offered if resources were available and conditioned on a supplementary contribution.

While retirement benefits for disabled and other workers' categories were slim, old-age pensions were even more so, thanks to the application of a $50 \%$ reduction.

The minimum wage, another institutional innovation of the Vargas era, born in 1936 and still a linchpin of labour rights, began to be regulated by the federal government in 1940. Its nominal value was set very low; under no circumstance would it suffice to meet a family's needs in terms of food, clothing, hygiene, and transportation, as the law that created it imagined. Moreover, the minimum wage varied across 14 different administrative regions. The minimum wage would only be established nationwide in 1984, under the military dictatorship that had been in power since 1964 .

The institutional framework that included and standardized labour laws and welfare rights would take on its definitive form in 1943 with the introduction of the Consolidated Labour Laws (Consolidação das Leis do Trabalho, or CLT), consolidating all laws that had been created since the Revolution of 1930 to govern individual and collective labour relations (individual contracts and collective agreements; workdays, vacation, and weekly rest; protection for workers, women, and children; occupational medicine, labour courts, etc.).

In 1945, shortly before he was forced out of office, Vargas approved a decree creating the Brazilian Institute of Social Insurance, which was

\footnotetext{
${ }^{13}$ A total of $99 \%$ women, according to the 1940 Census (Slivnik 2018: 108).

${ }^{14}$ For more details, see Slivnik (2018).
} 
designed to centralize and unify all existing social insurance regimes. The decree would be revoked by his successor that year, however, leaving the fragmentation, selectivity, and minimal efficacy of Social Security intact.

Nevertheless, the creation of the CLT seems unquestionably tied to a desire to resolve the social question-understood in that moment as a labour question-in that it established the positive value of productive work.

In the scenario depicted by the "myth of concessions", labour laws and social rights emanate directly from State action and are conceded by its representatives in a peaceful process (Castro Gomes 2005), moving past conflicts and struggles and addressing the social question ignored under the First Republic. The Estado Novo is seen to have thrown itself into the task of forging a social democracy, in spite of the ongoing suppression of individual and political freedoms.

Prevailing dissatisfaction with living and working conditions, even amongst those benefiting from regulated citizenship, may explain the outbreak of strikes and protests after the fall of the Estado Novo (1945) and the return to a democratic regime.

\section{5-1963: The Social Question as the Regional Question Under Democratic Rule}

Vargas was deposed by a military junta on the eve of the first democratic elections in 15 years. A new Constitution was ratified in 1946, which preserved the social rights secured over the course of the 1930s, as well as their exclusionary rules. The document represented a new commitment to democratic rule and political freedoms. It broadened political citizenship by extending the vote to all those over age 18, while still excluding the illiterate. The right to strike would be restricted and ultimately regulated by decree, effectively banning stoppages across nearly all professions (Schwarcz and Starling 2018). Not even this rule would prove effective, however. In 1946 and 1947, bottled-up grievances spi lt onto the streets again. 
Vargas was democratically elected and returned to power in 1950, having run on a campaign of expanding his nationalist, industrializing agenda-but not even this could placate the workers covered by his social legislation. In addition to factory strikes, mass mobilizations took over the streets again. In 1953, the March of the Empty Pots, against the cost of living and in support of wage increases, rallied 60,000 people in the industrial heart of the nation, São Paulo. The marchers' demands included price freezes, an expansion of the water and sewer networks, and reforms to extend protective legislation to rural workers, among others.

Shortly thereafter came the Strike of the Three Hundred Thousand, which took in countless industrial sectors. After a month of action, the government backed down and conceded an average salary increase of $32 \%$ (Schwarcz and Starling 2018). Beyond the salary increases, the general strike had a major impact in that it put the urban question back on the map of social demands. In the words of Leal (2011), spaces of reproduction-housing, transportation, basic sanitation, electricity, healthcare, schooling, postal services, and consumption-would reframe the essence of the social question through spontaneous action during this new phase of peripheral capitalist development.

Against a background of extreme social polarization, the Organic Social Insurance Law (LOPS) was passed in 1960, designed to unify legislation around the Institutes and Funds for retirements and pensions. Fleury (1994) describes LOPS as a second attempt to rationalize the system, the first having been Vargas' abortive Brazilian Institute of Social Security.

LOPS marks a fundamental change: it moves away from the fully funded model and introduces the public simple distribution model, as well as authorizing the inclusion of self-employed workers in cities as individual contributors (Teixeira 1990). "The focus shifted to standardizing benefits and broadening coverage-preserving the original exclusion of rural workers - and the end result was a demagogical gesture that worsened the system's financial straits even as it failed to expand its narrow financial base" (Fleury 1994: 194).

Instead of ebbing, this tension and social agitation would draw strength from the protagonism of new social actors, who had not yet been incorporated into the realm of regulated citizenship. The independent 
mobilization of rural workers would redefine the social question, which had hitherto been framed in terms of social legislation and an existing framework that marginalized them.

Small farmers and their families rose up across the country, calling for access to and legalization of the occupied land where they were working and resisting attempts to expel them. The struggle against the latifundia system entailed fighting both the concentration of property and the profound poverty to which the citizenship-deprived masses were subjected. These rebellions began in southern Brazil, but the Northeast would see the emergence of a peasant organization that would expand the social question beyond the urban industrial sphere.

The Peasant Leagues, formally constituted in $1955,{ }^{15}$ served to put land reform on the nation's political and social agenda. The right to land, here, was equated with the right to decent work, free of oppressive relations. The Leagues formed in the sugarcane fields, a region where the majority of the enslaved population had been taken during the colonial period. There followed four centuries of absolute, quasi-feudal control by coronéis, local landowners, whose power was now threatened by the independent organization of largely illiterate and destitute farm workers, forgotten by the Republic and by its democracy.

Reluctant to collaborate with the State, the Leagues moved to occupy fallow or abandoned plots of land to allow poor, exploited peasants to cultivate them and thus improve their standard of subsistence. They provided legal advice and medical assistance and defended members who were threatened or expelled by major landowners, who subsequently refused to compensate them for their investment in the land. On the whole, the Leagues worked to denounce violence as a way to regulate labour relations.

For the first time, working independently, the citizenship-deprived rural population would act to reframe the social question in Brazil.

Overlapping rural and agrarian issues, compounding the rural-urban conflict and the new shape of the urban question, would make approaches

\footnotetext{
${ }^{15}$ The Union of Rural Farmworkers and Labourers (ULTAB) had been created in São Paulo the year before, and it would become the National Confederation of Workers in Agriculture (CONTAG) in 1963.
} 
to the social question as a whole even more fraught. In 1963, practically faced with a looming insurrection, João Goulart's labour-friendly administration introduced two aggressive measures designed to meet the demands of rural workers.

First, the legislature approved a bill that had been tabled since 1956, creating the Rural Workers' Statute (EST), which finally extended to rural wage labourers the same labour rights which urban workers had enjoyed for two decades: unionization, a minimum wage, vacation, paid weekends, advance notice, and compensation. The statute also included special measures designed to protect women and children. While undoubtedly innovative, it was also selective, leaving out the vast majority of the diverse workforce in the countryside. Even so, its potential to reform and modernize social relations in the countryside posed such a threat that the EST would be revoked in 1973, during the most repressive period of the military dictatorship.

Second, the government created the Rural Worker Assistance Fund (FUNRURAL). This pioneering measure stipulated that labourers in the countryside would have the right to $1 \%$ of the sale price of their products. The funds would be channelled through the Institute of Retirement and Pension Benefits for Industrial Workers (IAPI). In practice, the programme ran consistent deficits, given obstacles to revenue collection. It would be reformulated and made independent, with an administrative structure of its own, in 1971, under the military regime.

In both instances, these attempts to regulate citizenship for rural workers and small farmers proved unsatisfactory, as the concept represented a threat to the power of agrarian oligarchies, which frontally opposed the logic of individual and social rights (see Ondetti, in this volume).

\section{4-1988: Dictatorship, the Authoritarian Modernization of Social Insurance, and the Struggle for Democracy}

The authoritarian context that followed the civil-military coup of 1964 was marked by the suppression of political freedoms and the furious repression of all opposition. It gained decisive support from the urban 
middle classes, fuelled by their dread of Communism and the consequences of prolonged economic stagnation. Buoyed by these fears, a military dictatorship would govern the country for the next 21 years, with a technocratic model of development that attained eye-popping growth rates (11\% per year from 1968 to 1973 ). This growth lent some legitimacy to the military government; at the same time, inequality also deepened.

Surprisingly, amidst a severe policy of wage reduction, which would diminish the purchasing power of the minimum wage and the working classes, the military regime completely reorganized the social insurance system, in an overhaul focused on efficiency. The system would undergo not one, but two profound administrative reforms.

The first reform came in 1966: the unification of all IAPs, with the exception of the institute for civil servants (IPASE), led to the creation of the National Institute of Social Insurance (INPS). The authoritarian regime was able to overcome resistance from unions, ${ }^{16}$ aided by their lack of funding. The union base was stifled, and control of the system was shifted to a public structure, centralized at the federal level.

Those covered by the INPS were entitled to retirement, pensions, and other social insurance benefits, as well as medical treatment at partnering public or private hospitals. These beneficiaries were formally employed workers (and their dependents), those with their employment record books up to date. Left out were the informally employed, domestic workers, the clergy, and rural workers. The reform established a compulsory contribution rate for employers and employees, and the benefit calculation rules were applied uniformly, regardless of each sector's organizational strength.

This was yet another step towards the universalization of the system. However, this unification was motivated less by universality than by efficiency, as it preserved occupational distinctions at its foundation. Civil servants, for example, were maintained in a parallel system along the lines of the old IAPs. In 1968, however, the regime began allowing those not

\footnotetext{
${ }^{16}$ Werneck Vianna (1998) recalls that previous attempts to unify the IAPs under democratic regimes failed because union and social insurance activists mobilized workers in protected occupations in defence of their rights, thus preserving their political privileges.
} 
formally employed-employers, as well as the self-employed-to contribute to the system independently. This expanded the system's financial base, and the improvement in coverage was taken by some as compensation for the repression of social demands (Teixeira 1990).

Another creation from this period was the Severance Indemnity Fund (Fundo de Garantia por Tempo de Serviço, or FGTS), a sort of unemployment insurance instituted after lobbying from the business sector. Formally employed workers were entitled to a savings account in their name, linked to their work contract, into which a sum corresponding to $8 \%$ of their salary would be deposited on a monthly basis. Those dismissed without cause would be able to access the funds in the account. In fact, the FGTS was introduced to make it legal to fire workers who'd been continually employed for over ten years, since under the terms of the CLT they had achieved estabilidade (tenure) and could not be dismissed.

Another important institutional innovation that arose from this restructuring, led by the now-unified Ministry of Labour and Social Insurance, was the framing of a national healthcare system that privileged an assistance-based approach funnelled through private networks. It was at this point that, as part of its economic development project, the military government supported the growth of a powerful medical-industrial complex, driving the privatization of medical assistance, whether through purchases in the private sector funded by Social Security or public subsidies for the construction of private hospitals. This would kick-start the process of the internationalization of the healthcare system, as multinational companies arrived in Brazil to meet the healthcare consumption demands of the rising middle classes.

In the field of healthcare, a new pattern of stratification manifested itself. Low-income workers who were currently formally employed were treated at public hospitals, institutions plagued by deficient financing and with dismal records in terms of patient outcomes. As increased demand led to bottlenecks, new routes of access to private medical services emerged, company health plans chief among them. The result was that State increasingly purchased third-party services on the market to meet the needs of social insurance beneficiaries (Werneck Vianna 1998). Meanwhile, the middle classes and those with significant purchasing power were drawn in by the promise of better care through private 
medical institutions, driven by fiscal incentives (individual tax deductions ${ }^{17}$ ) and rising incomes. All the while, the poor, those deprived of citizenship, remained at the mercy of a meagre network of philanthropic institutions.

At the same time, "exclusionary expansion" continued to hold sway, with the gradual, almost always incomplete incorporation of new categories. PRORURAL, or the Programme of Assistance for Rural Workers, was instituted in 1971; despite the new name, this was merely a revamped version of the 1963 FUNRURAL. In spite of challenges to implementation and its negligible functional efficacy, PRORURAL did provide textual reinforcement of social rights for groups that had previously gone wholly unprotected or had only patchy coverage.

Another relevant extension of coverage came with the 1972 regulation of the profession of domestic worker and its subsequent incorporation into the social insurance system. As recently as 2013, the majority of working women in Brazil were domestic workers. But the law remained a dead letter.

The second and most significant reform of the social insurance system under the authoritarian regime would come in 1977 when the military government completely overhauled the National System of Social Insurance and Assistance (SINPAS). For the first time, social assistance was included in the system's organizational structure. In an attempt to ensure better management, different services were addressed by a variety of bodies. Social Security remained with INPS; medical care was taken over by the National Social Insurance Medical Assistance Institute (INAMPS); ${ }^{18}$ and the Brazilian Assistance League Foundation (FLBA) ${ }^{19}$ and National Foundation for the Welfare of Minors (FUNABEM) ${ }^{20}$

\footnotetext{
${ }^{17}$ The 1966 tax reform and the 1967 Constitution inaugurated a new array of tax deductions.

${ }^{18}$ Other creations of the period included the Institute for the Financial Administration of Social Insurance and Assistance (IAPAS), tasked with collecting contributions, overseeing resources, and managing the system's funds, and DATAPREV (Public Pension System Data Base), which worked to systematize and manage the network's data.

${ }^{19}$ Originally the Brazilian Assistance League - the organization was founded in 1942 to provide aid to the families of soldiers serving in World War II. It was reorganized as a Foundation in 1969 by the dictatorship.

${ }^{20}$ Created in 1964 . Under the military dictatorship, juvenile delinquents came to be seen as a "national security issue", and there emerged a consensus that poor children belonged in boarding schools. The repressive policy of sending delinquents to reform school lasted through the start of the re-democratization process in the mid-1980s.
} 
would be brought in to address the indigent population, albeit employing a repressive approach. In practice, the system continued to segregate services by clientele. More troublingly, as this assistance was institutionalized, it developed a clear punitive bent; the groups it attended almost exclusively were single mothers (LBA) and juvenile delinquents (FUNABEM), both targeted by public policy by virtue of their deviant behaviours.

Such a distorted perspective of social assistance explains why the government implemented no poverty-fighting programmes supported by cash transfers to mitigate the hardships suffered by those unable to meet their most basic needs. Poverty mitigation, meanwhile, remained largely charitable and provided by private institutions.

As the 1970s' decade drew to a close, the economic miracle began to melt away and the social question was channelled into the struggle for democratic freedoms, amnesty (1979), and political opening. With the support of the Catholic Church, society organized and mobilized in working-class neighbourhoods. Associations of all stripes were formed, rooted in a shared logic of resistance to the dictatorship. One item on the agenda, just as at the turn of the century, was the cost of living: the working population bore the brunt of skyrocketing inflation (211\% in 1983) and considerable wage cuts, which reduced the real value of the minimum wage by over 50\% (Lavinas 2017). Though GDP per capita rose $6.1 \%$ p.a. from 1970 to 1980 , the Gini index, as measured by household income, went from 0.504 in 1960 to 0.592 in 1980 . This was the rise of the "new trade unionism" (Schwarcz and Starling 2018), which broke away from the state-controlled model of the Vargas era and opened up a phase in which leaders would seek to forge a unified representation for the working classes, moving beyond socio-occupational categories.

Pressure to put an end to the dictatorship grew across the country. So, too, did reactions from within the armed forces from those opposed to a return to democratic order; repressive mechanisms which had never been dismantled were set to work again.

On January 15, 1985, a new civil government inaugurated the New Republic, and a Constituent Assembly would be called in 1987 to draw up the nation's new carta magna. Rarely had Brazil seen such widespread mobilization and engagement with the constitutional debate. Through 
associations, committees promoting grassroots participation, activist gatherings, and unions, petitions would be drawn up and hundreds of proposed amendments were submitted from all sectors of society. This may serve to show how it is nearly impossible to speak of the social question in Brazil, given the enmeshed tangle of issues that would come to shape the Citizen Constitution of 1988. That Constitution would become the repository of collective hopes of addressing a whole variety of social issues.

Among the groups most active in drawing up the section on social rights, scholars, politicians, and activists from the field of Social Security took pride of place.

\section{8-2015: A New Wave of Democracy-Social Security for All21}

The 1988 Constitution establishes citizenship as one of its fundamental pillars. Among its explicit objectives are the construction of a free, just society rooted in solidarity, the eradication of poverty and the reduction of social and regional inequalities, as well as the welfare of all, without prejudice or any form of discrimination. The document guarantees the participation of civil society across a variety of forums (healthcare; education; social assistance) to democratize the decision-making process.

The process of re-founding the nation (Paoli 1989) and the return of democratic rule, would, however, unearth issues that had to be addressed urgently. Extreme poverty, that long-stifled element of the social question, finally came to the fore. It had worsened belatedly, not as a consequence of the waves of industrialization and the impoverishment of the working classes—-which predated workers' mobilizations — but as a manifestation of inertial inflation, which had been forcing up the prices of basic necessities since the 1970s. In 1993, hyperinflation hit 2477\% (IPCA-IBGE, Contas Nacionais 2018), threatening the very survival of multiple sectors of the population.

${ }^{21}$ Part of this section draws on Lavinas (2017). 
The fight against hunger would become a central element of the social agenda. As in the past, it would focus on the struggle against the cost of living. The first major social mobilization along these lines was the campaign for Citizen Action Against Hunger, Extreme Poverty, and For Life.

Poverty as a social question would become a central part of the landscape of social struggles, as the social protection system enshrined in the 1988 Constitution, with the creation of Social Security, was regulated and implemented. For the first time, the term "Social Security" was added to the body of the law, and Brazil's poor became entitled to rights.

The Constitution of 1988 was a watershed moment in Brazil in terms of social rights. With it, the country would be transformed. Articles 194 and 195 of the Constitution implemented a Social Security System, comprising healthcare, pensions and other labour-related benefits, welfare schemes, and unemployment insurance (Article 201). Under the Citizen Constitution, healthcare is defined as universal and free of charge. Nonetheless, private institutions may work to complement the Unified Health System (Sistema Único de Saúde, or SUS), in keeping with directives established by the public system. Social insurance, including unemployment insurance, is contributory and guarantees a relatively broad array of types of coverage in cases of forced or definitive inactivity (payas-you-go model). Social insurance also guarantees pensions and other benefits to small family farmers irrespective of prior contribution records This is a major achievement in the process of universalizing access to pensions for both rural and urban workers. Non-contributory old-age pensions to rural workers, both male and female, are paid out of the general budget of the Social Security System (collecting contributions from both employees and employers). They are not considered welfare benefits but a solidary principle in order to promote equality of rights. Social assistance schemes, meanwhile, introduce the right to a safety net for the demonstrably poor, subject to means test.

The incorporation of social assistance under the umbrella of Social Security comes as an extremely relevant institutional innovation. Until this point, care for the poorest and destitute had been mostly limited to charity and philanthropic organizations, but then it has become the State's legal obligation (Lavinas et al. 2017). 
Other equally important rights were written into the letter of the law: the right to housing and the social function of the city and urban property; the social function of agricultural property (see Chap. 10, in this book) and the promotion of agrarian reform; food security; the right to free and secular education at all levels (day care and preschool; primary, middle, and high school; college; and youth and adult education); and the right to security, to say nothing of the Constitution's considerable expansion of labour and union rights. Eduardo Fagnani and Flavio Tonelli Vaz write that the Constitution of 1988 inaugurated "a social protection system inspired by the values of the social welfare state" (2013: 98-99) as seen in Europe.

Finally, the Constitution reaffirmed the ILO model of tripartite financing for Social Security. Should the National Treasury need to transfer fiscal resources to the General Social Insurance Regime (RPPS, which is contributory), one might argue that the situation would not constitute a "deficit", but rather a follow-through of a constitutional responsibility (Fagnani 2005).

To shore up the social order outlined in the Constitution, the members of the Constituent Assembly established a specific budget for Social Security, set apart from the fiscal budget (revenues from which would go towards financing other social rights, such as education, sanitation, housing, etc.). The idea was to ensure a measure of fiscal autonomy for Social Security by feeding it with certain exclusive revenue streams drawing on a variety of sources.

With this in mind, the Social Security budget draws off of contributions from employees and employers and from voluntary contributors (self-employed workers, idle working-age adults, etc.), in keeping with the logic of contributory Social Security. It is also fed by so-called social contributions, which include taxes on consumption, reflecting a societywide contributive effort, or on company earnings, rather than income tax. Finally, there are also contributions from lotteries and revenue from the ministries that make up the various sectors of Social Security, although these are modest sums. In theory, all of these revenue sources are tied to Social Security and supply it exclusively. However, since 1994, the federal 
government started slashing the Social Security budget in order to shift funds over to the fiscal budget, applying a 20\% cutback ${ }^{22}$ (dubbed as the Unbinding of Federal Revenue or DRU).

\section{National Social Insurance Scheme}

Brazil adopted two public social insurance regimes in addition to the complementary fully funded regime, which is voluntary. They were all instituted by the Social Security Organic Law n. 8.212 of 1991.

The General Social Insurance Regime (Regime Geral da Previdência Social, or RGPS) provides pensions and other contributory benefits for workers in the private sector, and is operated by the National Social Security Institute (Instituto Nacional da Seguridade Social, or INSS). The Special Social Insurance Regime (Regime Próprio da Previdência Social, or RPPS), meanwhile, covers civil servants at all levels of government and the military, and it is included in the fiscal budget (not in the Social Security budget). Finally, the 1988 Constitution created the Complementary Social Insurance Regime, served by open (run by banks and financial institutions) and closed (company-based) private pension funds, a system designed to complement workers' incomes after their definitive retirement. These complementary fully funded pension schemes are subject to private regulations. The open private pension fund are voluntary, whereas the company-based funds tend to be mandatory, reaching the fraction of wages that surpasses the public contribution cap (see later).

The RGPS is contributory and compulsory for workers in the private sector covered by the Consolidated Labour Laws but also takes in a broad range of voluntary policyholders (working-age adults, the self-employed, individual micro-entrepreneurs, and rural producers). It is a pay-as-yougo regime, with rules that, though distinct, cover both rural and urban dwellers.

The contribution rate is $20 \%$ of received remuneration or any contribution between the social insurance floor (the current minimum wage) and the contribution cap, set at $\mathrm{R} \$ 5840.00$ (USD 1500) per month in

${ }^{22}$ Lifted to 30\% in August 2016. 
2019. This $20 \%$ is split between workers and employers; the workers' part is graduated, varying from $8 \%$ to $11 \%$, while the rest is the employer's responsibility. Non-salaried contributors pay the full $20 \%$, with the exception of Individual Micro-Entrepreneurs (Microempreendedores Individuais, or MEIs), for whom the rate was lessened (invariably 5\% of a minimum wage), and small family farmers, who are taxed $2.1 \%$ of the value of the gross revenue from the sale of their production. In addition to this category of contributor, classed as "specially insured", rural social insurance includes two other forms of membership, which fall under the general contribution rules for the RGPS. ${ }^{23}$

The array of benefits provided by social insurance is a varied one, ranging from retirement plans and pensions to paid maternity leave, unemployment insurance, family allowance, sick pay, accident benefits, and aid for inmates' families, among others. Not all working categories are eligible to all benefits. The regulations vary according to the benefit and the beneficiary, but over recent years, they have trended towards greater uniformity, even between the RGPS and the RPPS (for instance, the floor and the cap are the same across both regimes).

As of 2019, approximately 30.3 million retirees and pensioners are covered by the RGPS. Around two-thirds of all RGPS' monthly retirement benefits and pensions amount to the social insurance floor, which stands at the minimum wage. Of all benefits, $80 \%$ fall below the level of two minimum wages. Around $85 \%$ of the elderly population $(60+)$ is covered by social insurance or assistance old-age benefits (Continuous Cash Benefit-BPC, see later) in Brazil.

A broad pension reform was approved in 2019, with the purpose of unifying both regimes (private sector and civil servants) as recently achieved in China (see Chap. 3, in this book) and trying to impose a short-term transition towards a fully funded compulsory system. This reform will have further impacts on the Social Security system as a whole, negatively affecting the healthcare system and welfare schemes.

\footnotetext{
${ }^{23}$ In addition to the "specially insured worker" (a category exclusive to small rural producers working on family farms), rural social insurance also includes the categories "individual contributor" (rural producer and self-employed worker) and "rural employee" (worker who provides services of a rural nature to an employer on a non-sporadic, remunerated basis). For individual contributors, a $20 \%$ rate is levied on the base salary, while rural employers have 8,9 , or 11 percent of the base salary withheld and levied by their employer.
} 


\section{Social Assistance}

The right to a minimum level of protection by the State has completely reconfigured the social pact. Now, the Organic Social Assistance Law (LOAS, Law n. 8.742), passed in 1993, guarantees a minimum wage to poor senior citizens (aged 65 or older) and the handicapped living in families with per capita household income below one-fourth of the current minimum wage. The number of recipients of the BPC (NonContributory Regular Pension) amounts to 4.9 million. The monthly benefit corresponds to a minimum wage, equivalent to $\mathrm{R} \$ 998$ in 2019. As stated by the Constitution, it is universal, though means-tested, applying to both rural and urban areas.

In parallel, since 2003, those who are not eligible for a BPC— that is, millions of children, young adults and able-bodied adults-can now qualify for a Bolsa Família stipend. In this respect, Bolsa Família went on to fix the limited coverage imposed by the eligibility criteria of the BPC. As an anti-poverty programme, it is less costly than BPC, given the difference in the average benefit-which in the case of Bolsa Família is $\mathrm{R} \$ 185$ (US\$ 48) per month. The household benefit is subdivided in a basic stipend and a variable one paid for children or youth aged $0-17$. In 2019, while federal spending with Bolsa Família corresponded to $0.48 \%$ of Brazilian GDP, the BPC represented 0.88\% (Lavinas 2020). Targeting mechanisms also differ; unlike the BPC, Bolsa Família recipients are subject to controls and conditionalities (school attendance, medical visits, immunization). In 2019, 14 million families are Bolsa Família beneficiaries, a headcount that certainly falls short of the total target population. "Bolsa Família" has been recognized nationally and internationally as an exceptional public poverty-fighting policy. None of this, however, was enough to ensure that the programme be enshrined as a right, ensuring full coverage for its target population. As a non-right, "Bolsa Família bends to budgetary logic and fails to expand its coverage as a countercyclical measure, as might be expected" (Lavinas 2017: 131). 


\section{The Unified Healthcare System}

The utopia of healthcare for all is undeniably the hallmark of not just the 1988 Constitution but also the entire societal ideal in play at the time. The 1988 Constitution created the Unified Health System (Sistema Unico de Saúde, or SUS), specifically as a counterpoint to the trend towards the privatization of Brazilian healthcare, inherited from the years of the dictatorship. It was authorized by the SUS Organic Law n. 8.080 of 1990 .

The principle behind the public healthcare system, inspired on universal European models, is "health and democracy". The slogan speaks to the basic idea behind the public health movement, which led to the healthcare reform, as well as to its mobilizing power. The aim is to break away from the legacy of liberal, profit-oriented medicine and cut down on the use of the designation "philanthropic" for healthcare institutions. In their place would come a public system committed to full service, universal coverage, and equal access.

Nevertheless, SUS does not guarantee full public provision, since most services are contracted out to the private sector via concessions. Despite the tremendous expansion of the public health network in the 1990s and its open-door treatment policy, private providers grew quickly, gained momentum, and ultimately drained SUS funding through tax waivers and tax credits. To give some sense for the contradictions and ambiguities that plague healthcare policy, total public spending at all levels of government on healthcare stands at $4 \%$ of GDP (multilateral agencies recommend 6\%). Private spending, meanwhile, which is largely out of pocket, has come to $5.5 \%$ of GDP. The public network treats $75 \%$ of the population, while the other $25 \%$ patronize the private sector; this is an eloquent testament to the twinned, hybrid health system in Brazil.

Ever since its creation, the Unified Health System has suffered from chronic underfinancing as a result of the government's decision to support the expansion of the private sector-which is now increasingly international and financialized. To this day, the healthcare plan market, created in 1968 by the military regime, is being underwritten by hefty tax incentives. Ocké-Reis and da Gama (2016) estimate that, between 2000 and 
2013, tax credits on healthcare (through waivers) in relation to total expenditures by the Ministry of Health remained practically stable, around $30 \%$ per year.

Programmes such as Farmácia Popular, which allows for the free distribution of medication and has extremely high approval ratings, meet just one-third of prevailing demand. The result is that medications are the fifth quintile of the income distribution's number one healthcare expense (Lavinas and Gentil 2018). In short, the Brazilian health system remains deeply stratified by income.

At its birth, then, Social Security was marked by a mixture of improvements and ambiguities that reflect historic problems and the challenges posed by multiple social questions. This is due in part to prevailing macroeconomic policy, which has given no quarter to a more effective universalization of social rights. Social spending has risen significantly, but it remains predominantly concentrated in cash transfers- they make up for $68.8 \%$ of social spending across all levels of government-as opposed to in kind provision (Lavinas 2017)—which has been seen to have much broader redistributive effects and to homogenize the patterns of social reproduction across social classes.

The importance and scale that the social protection system acquired through the consolidation of Social Security broadened the process of social inclusion, which was also driven by a new cycle of economic growth that incorporated tens of millions into the mass consumer market who had previously been excluded or only marginally included. This would become clear at the peak of the social-developmentalist model (2003-2014), which combined three drivers of growth: a renewed focus on natural resources, the expansion of the domestic consumer market, and investments (Bielschowsky 2012).

But amidst a period of wage recovery, with broadened poverty-fighting programmes, access to credit, and incorporation into the mass consumer market, Brazilians_- now armed with citizenship_took to the streets en masse to call out for public transportation, quality public healthcare and education, and affordable housing.

These would ultimately attract anti-Workers' Party right-wing groups and serve as a magnet for the frustrations and aspirations of multiple 
political positions' deepening political divergences. The Landless Workers' Movement (MST), created in 1984, and the Homeless Workers' Movement (MTST), from 1997, are evidence that forms of exclusion persist in both rural and urban environments. Democracy and the consolidation of a social protection system-understood as access to social ownership-have not alleviated the hardships faced by those seeking to live off the land they work or those who hope to find a decent roof under which to live.

The Black movement, and its struggle for racial equality, is another social force that has redefined the terms of the social question in Brazil. While the 1989 Caó Act made racism a non-bailable crime with no statute of limitations, it proved necessary to create a Statute of Racial Equality in 2010 to ensure the practical application of equality of opportunity; the defence of individual, collective, and diffuse ethnic rights; and the fight against discrimination. Black and Brown people represent $52 \%$ of the Brazilian population, but they are disproportionately poor, undereducated, and most vulnerable to violence, especially when wielded by the State. Being a Black, in Brazil, is still "a matter for the police", as the saying goes.

A hundred years after the abolition of slavery, the recognition that racism is an essential aspect of the social question in Brazil made it possible to take steps away from colourism and a long past of exclusion. Legally mandated diversity has advanced, moving towards the universalization of access. The 2012 Law of Social Quotas, for example, set aside 50\% of admission spots at federal public universities for young people from lowincome families (per capita household income of up to 1.5 times minimum wages) who attended public high school, a measure which significantly boosted Black enrolment. The 2014 Law of Racial Quotas set aside $20 \%$ of federal jobs for Black, Brown, and Indigenous candidates.

The social question in twenty-first-century Brazil remains defined by the ongoing struggle for the recognition of social cleavages that have become naturalized and masked, and by the implosion of certain barriers that reinforced selectivity, stratification, and discrimination. 


\section{Conclusion: The Social Compact at Risk}

This chapter has sought to systematize multiple facets of the social question in Brazil, covering a period that opens with the incipient debate about social protection begun in the late 1910s (for a summary, see Table 9.1). Looking back on the century-long process of the construction of a system of Social Security in a peripheral economy marked by deep structural heterogeneity, we may see that the layers of recognition (Leisering 2019, see also Chap. 1 of this book) of the social question have continued to multiply and remain intertwined and indivisible.

Social policy has expanded both under democracy and dictatorship. Under the first period of dictatorship (Vargas, 1930-1945), social policy has been instrumentalized as a means of social control. Labour relations were at the foreground of social policy and labour legislation built on the denial of the civil rights of workers and citizens. During the second period of dictatorship, 1964-1985, Social Security was modernized.

We have seen the continual, growing advance of coverage against risks, which moved from the regulated citizenship of the first phases of state-led industrialization to the universalization of rights enshrined in the Citizen Constitution of 1988. The social question, newly framed in terms of social inclusion, redefined the scope of social policies and reaffirmed universalistic value orientations.

While the early social security and labour legislation would organize the labour market to ballast the process of industrialization and the conservative modernization of Brazilian society, the consolidation of citizenship belatedly introduce an entirely new dynamic.

The re-democratization of Brazilian society in 1988 allowed for the creation of a relatively solid, broad system of social protection bolstered by exclusive funding, which included both labour rights and the struggle against poverty.

This being said, the realm of the public provision of goods and decommodified services is also a stronghold for resistance to the equalization of opportunities. We have not yet been able to bypass income and status as forms of access to quality education, healthcare, or even public safety, although identity-driven movements are currently leading the 
9 The Anatomy of the Social Question and the Evolution...

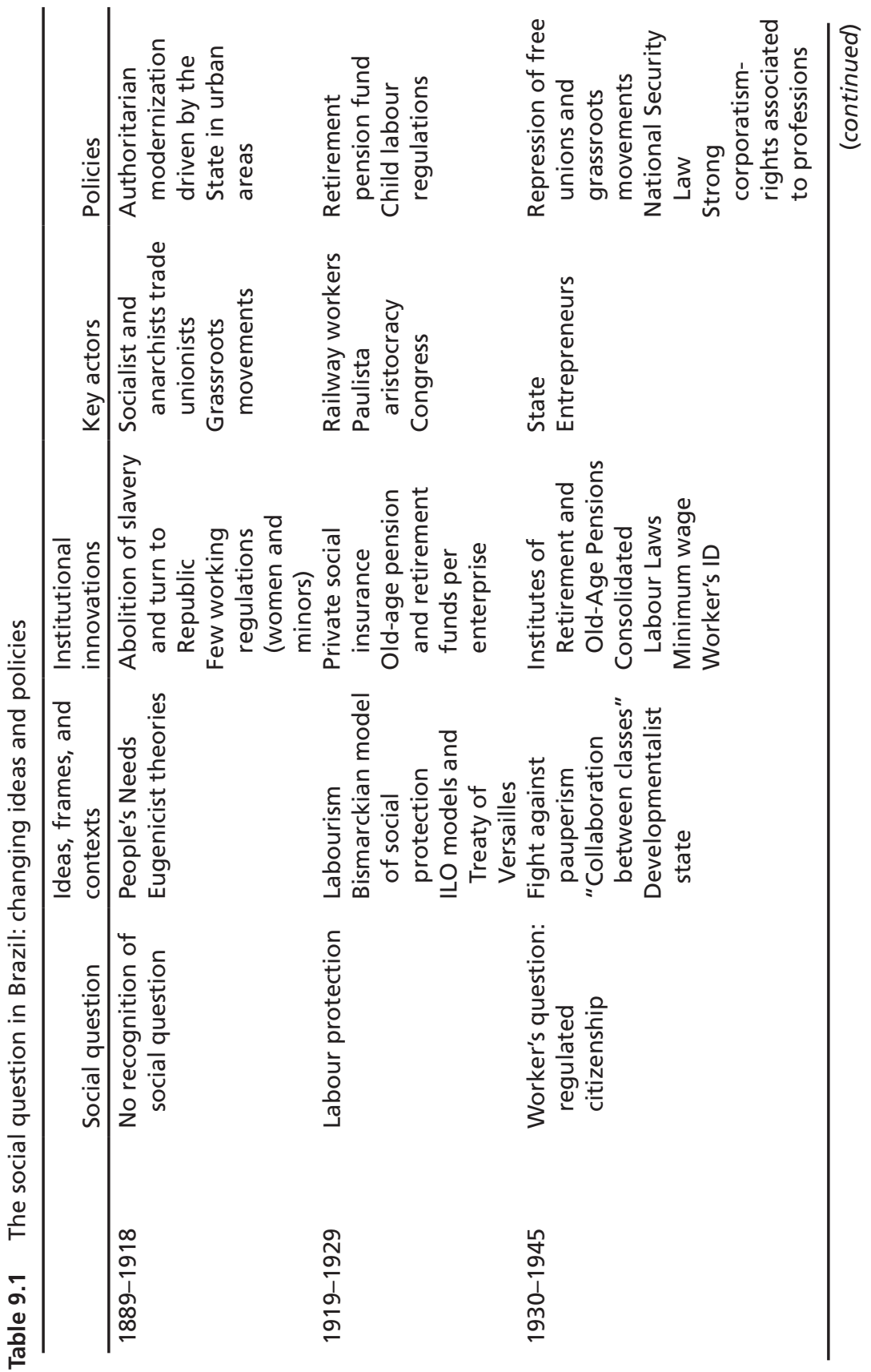




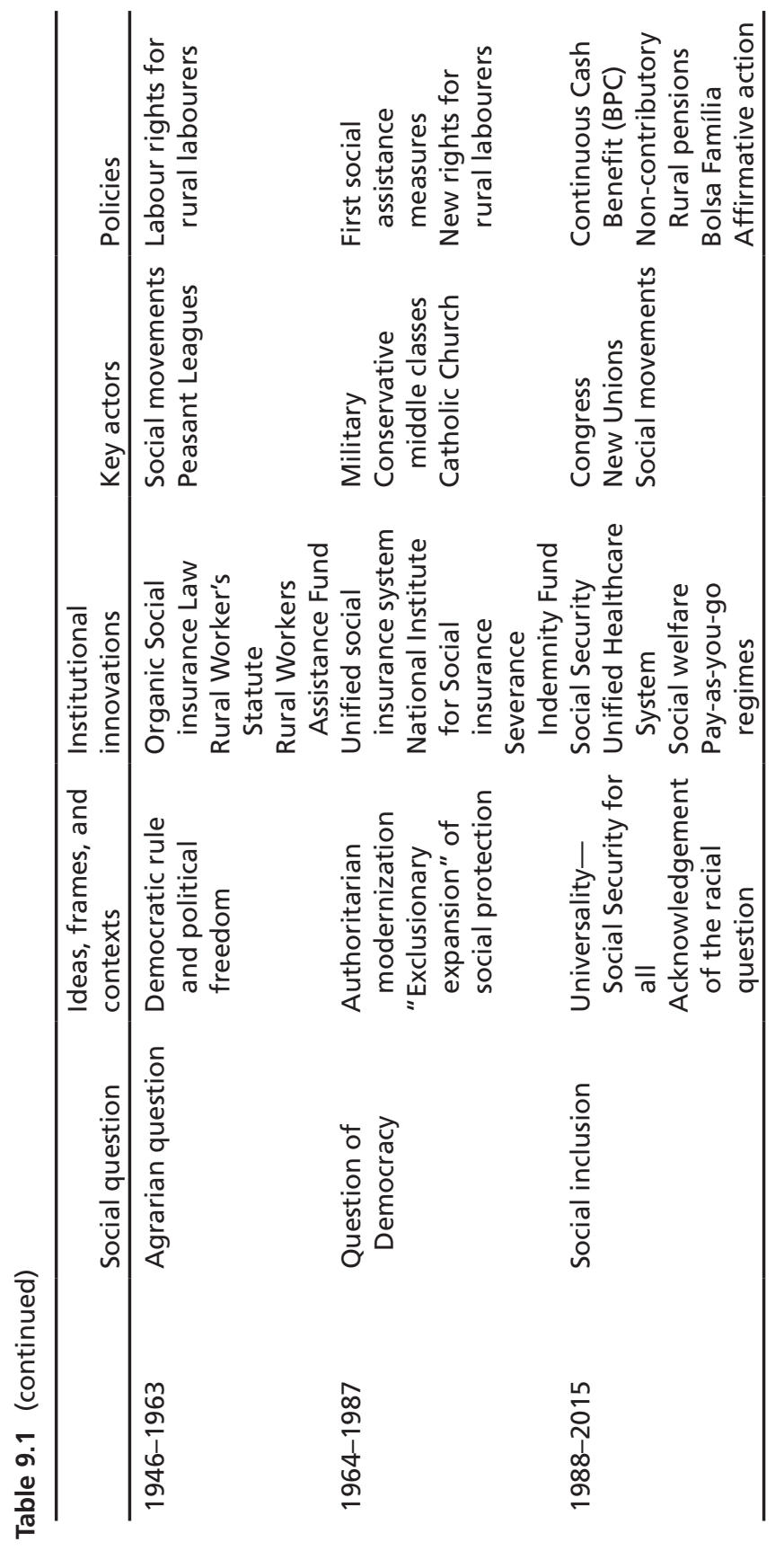


charge in denouncing how this exclusionary universalization acts in a discriminatory fashion and undermines citizenship.

This positive and promising outlook is nevertheless at stake and has been under attack since the impeachment of democratically elected President Dilma, in 2016, and the following election of far-right President Jair Bolsonaro, who took office in January 2019 and is openly committed to the dismantling of the public sphere in Brazil.

Two labour reforms, adopted in 2018, have already reinforced informality and work precariousness, representing a blow to social rights. With declining contributions from employees and payroll exemptions for employers, the Social Security budget will soon be stifled and unable to fund pensions and other labour benefits. As a consequence, the structural heterogeneity that decades of industrial policymaking and various developmentalist models failed to overcome will amplify again, magnifying inequalities, as is already the case. Sick-pay, occupational accident insurance, and maternity leave are benefits in peril. They risk being moved from the scope of the Social Security system to the financial sector, through contracts with private insurers. New waves of pension reform will probably undermine further the public pay as you go system.

Even the Bolsa Família programme, relying on targeting mechanisms, is now contested, collapsing the most innovative dimension of the 1988 social compact: the right to minimal protection from the State, through a subsistence income. A sign that compensatory anti-poverty schemes, albeit cheap and central to the logic of residual welfare policies, do not escape the grip of the neoliberal mindset that governs today's Brazil.

The assault on the social through disenfranchisement, if unstopped, will interrupt and prevent social citizenship from fully consolidating in Brazil.

\section{References}

Bielschowsky, Ricardo (2012) Estratégia de desenvolvimento e as três frentes de expansão no Brasil: um desenho conceitual. Economia e Sociedade 21 (especial): $729-747$. 
Cardoso, Adalberto (2010) Uma utopia brasileira: Vargas e a construção do Estado de bem-estar numa sociedade estruturalmente desigual. DADOSRevista de Ciências Sociais, Rio de Janeiro, 53, 4: 775-819.

Castro Gomes, Angela M. (1979) Burguesia e trabalho. Política e legislação social no Brasil 1917-1937. Rio de Janeiro: Editora Campus Ltda.

Castro Gomes, Angela M. (2005) A Invenção do trabalhismo. Rio de Janeiro: FGV Editora, 3a ${ }^{a}$. Edição.

D’Araújo, Maria Celina (2019) Estado, classe operária e políticas sociais. $O$ Brasil republicano. Ferreira Jorge and Delgado Lucília de A. Neves, ed. Vol.2. 2ed. Rio de Janeiro: Civilização Brasileira, 203-228.

Dos Santos, Wanderley G. (1979) Cidadania e justiça. Rio de Janeiro, Ed. Campus.

Fagnani, Eduardo (2005) Politica social no Brasil (1964-2002): entre a cidadania e a caridade. PhD Thesis, Campinas: Instituto de Economia da UNICAMP.

Fagnani, Eduardo and Flavio Tonelli Vaz (2013) Seguridade social, direitos constitucionais e desenvolvimento. In Políticas sociais, desenvolvimento e cidadania. Fonseca, Ana and Eduardo Fagnani editors. São Paulo: Fundação Perseu Abramo, pp. 93-113.

Fleury, Sonia (1994) A montagem do padrão de seguridade social na América Latina. In Estado sem cidadãos: seguridade social na América Latina [Online], Sonia Fleury ed. Rio de Janeiro: Editora Fiocruz.

IBGE, Contas nacionais 2018, Time series.

Lavinas, Lena (2017) The takeover of social policy by financialization. The Brazilian paradox. New York: Palgrave Macmillan.

Lavinas, Lena and Denise Gentil (2018) Brasil anos 2000: a política social sob regência da financeirização. Novos Estudos, 37.2:191-211, São Paulo: CEBRAP. Lavinas, Lena (2020) The anatomy of the social question and its links to the Brazilian Social Security system. Entangled dynamics in shaping citizenship. Federal University of Rio de Janeiro, Institute of Economics, Discussion Paper 002/2020.

Lavinas, Lena, Denise Gentil and Barbara Cobo (2017) The controversial Brazilian welfare regime. UNRISD, Working Paper 2017-10. UNRISD project New directions in social policy: alternatives from and for the Global South. Geneva, November 2017.

Leal, Murilo (2011) A Invenção da classe trabalhadora (1953-1964). Campinas: Editora Unicamp.

Leisering, Lutz (2019) The global rise of social cash transfers. How states and international organizations constructed a new instrument for combating poverty. Oxford et al.: Oxford University Press. 
Malloy, Joseph (1986). Politica de previdência social no Brasil. Rio de Janeiro: Ediçôes Graal.

Ocké-Reis, Carlos O. and Filipe Nogueira da Gama (2016) Radiografia do gasto tributário em saúde 2003-2013. Nota Técnica 19. Brasília: IPEA.

Paoli, Maria Coeli (1989) Trabalhadores e cidadania. Experiência do mundo público na história do Brasil moderno. Estudos Avançados 3.7: 40-66. São Paulo Sept/Dec 1989.

Pio Vieira, Hermes (1978) Eloy Chaves, precursor da previdência social no Brasil. Rio de Janeiro: Ed. Civilização Brasileira.

Schwarcz, Lilia Moritz and Heloisa M. Starling (2018) Brasil: uma biografia. São Paulo: Companhia das Letras.

Slivnik, Andrej (2018) Previdência social no Brasil. Uma abordagem histórica (1923-1945). Master Dissertation. University of Campinas.

Teixeira, Aloizio (1990). Do seguro à seguridade: a metamorfose inconclusa do sistema previdenciário brasileiro, Instituto de Economia da UFRJ, Textos para Discussão n. 249, dez. 1990.

Werneck Vianna, Maria Lucia T. (1998) A Americanização (perversa) da seguridade social no Brasil. Rio de Janeiro: Editora Renan.

Open Access This chapter is licensed under the terms of the Creative Commons Attribution 4.0 International License (http://creativecommons.org/licenses/ by/4.0/), which permits use, sharing, adaptation, distribution and reproduction in any medium or format, as long as you give appropriate credit to the original author(s) and the source, provide a link to the Creative Commons licence and indicate if changes were made.

The images or other third party material in this chapter are included in the chapter's Creative Commons licence, unless indicated otherwise in a credit line to the material. If material is not included in the chapter's Creative Commons licence and your intended use is not permitted by statutory regulation or exceeds the permitted use, you will need to obtain permission directly from the copyright holder.

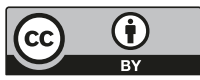

